\title{
Critical interventions in debates on the Arab revolutions: Centring Class
}

\author{
Sara Salem \\ Department of Politics and International Studies, University of Warwick, Coventry, UK
}

The three works under discussion are important interventions in the literature on the Arab uprisings, and constitute an attempt to rethink the Arab region through the lens of capitalism and class, an approach that has been somewhat under-represented in the broader literature. In this piece, I first briefly discuss the themes in each of the three works, before discussing elements in each that I find particularly useful. All three works conceptualise revolution as a process, and as a process that will take a significant amount of time. De Smet speaks of a permanent revolution, or lack thereof, Achcar speaks of a protracted and longterm revolutionary process, and Abdelrahman speaks of a long revolution. This serves to frame the events of January 25-February 12, 2011 as part of a longer historical trajectory. Moreover, each of the three works employs a critical methodology that pays close attention to the neoliberalization of Egypt over the past few decades, and how this has been tied to regional and international capital. This historical trajectory as well as close attention to capital and class makes these interventions particularly important in our contemporary moment.

Gramsci on Tahrir by Brecht De Smet is an important work on the 2011 Egyptian revolution that brings together a Marxist framework with empirical research on the events of January 25. Using a Gramscian approach, De Smet analyses the events of 2011 through the lens of revolution and counterrevolution. Revolution and restoration, hegemony, passive revolution and Caesarism are the key concepts De Smet works with in order to 'read the Egyptian revolution with Gramsci' (5). ${ }^{1}$ Focusing on both the time period leading up to 2011, as well as the five years from 2011-2015, he provides a detailed analysis that looks at the roots and trajectory of the 2011 events, as well as the eventual resurgence of a counterrevolution that appeared to be dominating by 2015. At the core of this counter-revolution remains the continued domination of the neoliberal strategy of accumulation. I focus on two particular arguments De

\footnotetext{
${ }^{1}$ Unless otherwise noted, all in-text citations refer to De Smet (2016).
} 
Smet makes that provides a useful lens through which we can look at the events of 2011, that of identifying the ruptures and continuities in Egypt's trajectory, and his analysis of the Nasserist era.

By the 1990s, Egypt's ruling class turned to economic liberalization and privatization to address its economic crisis and falling profit rates. Making use of the incorrect characterization of the private sector as inefficient and unproductive, the ruling class began to rapidly privatize key public sector companies in the 2000s. De Smet captures this period by claiming that '[s]tanding squarely behind private capitalists and landlords, the Mubarak state undermined the traditional patron-client relations between the subaltern groups and the ruling classes' (130). Because of this, rates of coercion accelerated. The end product was the 2011 revolution, which de Smet places in a long trajectory of revolution and counter-revolution in modern Egyptian history. The roots of the political crisis that emerged following the protests can be traced as far back as the reign of Muhammad Ali and the incorporation of Egypt into the global capitalist system. Certain structures that came into existence and that have survived over time-albeit in modified form—continued to condition Egypt's political economy in various ways which need to be understood in relation to the revolution. Moreover, each historical era since Ali has likewise produced its own structures as well as reproduced structures from previous eras. At very specific points, the materialisation of new relations of production dominated, notably following the 1952 revolution, during the Infitah period, and during the late Mubarak era. These specific points are particularly interesting because they represent moments of dynamism during which Egypt's political economy underwent tremendous changes.

What matters, however, is not just that we talk about history but the way we talk about it. The Gramscian approach is particularly useful here because it allows for an analysis of the Egyptian configuration of elites over time and space. Situated within historical materialism, Gramscian theory focuses on historicism (time) as well as both the national and international levels (space). It thus has a particularly complex understanding of history. The transition literature, for example, which has often dominated Middle East-oriented political science, has implicitly assumed a certain linear set of developments that must be followed for 'democracy' to materialise. A deep historicism, on the other hand, allows scholars to uncover trajectories, as De Smet has.

I have found both Gramsci's work as well as Fernand Braudel's work on the longue durée useful in approaching the events of 2011. Braudel is known for the concept of the longue durée and specified that different conceptualisations of time should co-exist in any analysis. His work actively challenged historians 


\section{S. Salem}

and social scientists that look at history as a series of dramatic discontinuities, and instead emphasised the continuous nature of history. This is opposed to views of history that focus on events or on the short-term, as well as views that understand history in a linear or schematic manner. Even views of history that focus on crisis moments, such as revolutions, were criticised by Braudel, who insisted that history should not be analysed through such events nor through the actions of individuals. History is beyond the awareness of individual actors: they make history, but history bears them along. The focus on continuity does not mean that Braudel ignored ruptures, events, or breaks. These are also important to temporal analysis, but should not be seen as the crucial driving force of history. He spoke of 'breaks' or events 'bursting forth' as a way of highlighting these ruptures, but his overall emphasis was on understanding the connecting threads in history. Moreover, when he did refer to breaks, he used a specific terminology that emphasised the cyclical nature of these breaks, such as 'turning points', 'swinging pendulum', 'turning wheel' and 'motors'. Braudel saw history as taking place through three temporal dimensions. The first is events, which are shortlived and dramatic; the second is conjectures, which are longer cyclical processes; and the third is the longue durée, a long historical span that changes slowly and plays a role in structuring the present.

In much of the work on Egypt, time is seen as linear and history is often recounted either through events or through influential individuals. Moreover, what is understood as the 'political' is given priority: political events such as changes in the head of state or governing bodies; changes in laws; and so on. Sometimes an 'economic' explanation is used to shed light these political changes, but overall there tends to be a distinction between the political and the economic, as well as the predominance of the political over the economic (cf. Abdelrahman 2012). An approach that relies on historical materialism as well as on Braudel would instead view history as non-linear and focus on the cyclical nature of history. While Braudel seems to have preferred the notion of history as continuity, historical materialists have amended this view somewhat by speaking of disjunctures. Points of rupture are as significant as continuity.

Here the notion of a trajectory comes in. A trajectory is made up of both continuity and disjuncture, and following Gramsci such a trajectory would depend on changes, or non-changes, in production relations. Conventional accounts tend to highlight specific historical eras. In other words, there is a tendency to present history in a conventional manner that is linear and associated with its rulers (e.g., the Nasser-SadatMubarak eras). Egypt during colonialism, and Egypt after independence is a common one, as well as the distinction between Egypt pre-1952 and Egypt post-1952. In such views of history, specific ruptures are 


\section{S. Salem}

emphasised, usually corresponding to political shifts in who is ruling the country. There is the reign of Muhammad Ali, followed by the British occupation and parliamentary democracy. There is a significant rupture in 1952 with the Free Officers and Gamal Abdel Nasser, followed by another significant rupture with Sadat and Infitah in the 1970s. The 2000s are then characterised as a relatively stable period, with a focus on either decreasing or increasing authoritarianism, depending on the author (among others, Bellin 2012, Stacher 2012, Osman 2010).

It is clear, however, that a historical materialist approach would identify different ruptures, as well as different explanatory variables for these ruptures and continuities. Muhammad Ali's reign would certainly constitute an important rupture, but for reasons related to production. His introduction of industrialisation, his emphasis on state-centered control of the economy, and his introduction of the capitalist mode of production all brought about significant changes in Egypt's mode of production and consequently both the social relations of production and the composition of the ruling class. The British occupation was important but did not constitute a rupture per se-many of the tendencies introduced by Ali and reinforced by Ismail continued under the British rule but in an accelerated fashion. This is because imperialism had already impacted Egypt's economy before the British occupied Egypt; indeed the reason for the occupation itself was that Egypt could not pay back debt that had accumulated following the spread of banking institutions. Following the occupation, there was an intensification of the capitalist mode of production as well as an increase in the amount and influence of foreign capital. Moreover, the various dates suggested for Egyptian independence-1919, 1922, 1936, 1952 and 1954 all seem to suggest a linear progression to full independence when, in fact, closer analysis reveals that 1936 was a regression compared to 1919. This shows the importance of not imposing a linear time analysis on events.

Nasser and the 1952 revolution constitutes another rupture, but not as extensive as assumed in the conventional approach to Egyptian history. It is clear that many of the tendencies that emerged during this period are repetitions of what occurred under Muhammad Ali, most notably a focus on industrialisation and state control of the economy. The state thus became the central actor once again, shaping the ruling class and the direction of the economy. Despite this similarity between the two ruling classes and the strength of the state in both eras it is crucial to point out the junctures that highlight differences. For example, under both ruling classes we see a focus on industrialisation, but the role of foreign capital was different. Similarly, both ruling classes had different relations to subaltern forces. This suggests that just because both 


\section{S. Salem}

re-emphasised the role of the state does not mean they were similar in other aspects. Moreover, the idea that the state was a central actor only during the reigns of Muhammad Ali and Nasser is also a problematic one. Indeed, we see that even during the historic blocs that came afterwards, the state remained central. What changed was the hegemonic project that the state's energies was directed towards.

Thus under the Nasserist bloc, despite claims to socialism, it is clear that this bloc was a capitalist one, defined by the ideology of nationalism. Here the state was used to push for industrialisation and was under direct control of the military. Later we see that when neoliberalism was introduced, the state was a key player in the liberalisation of the economy. The formation of the National Democratic Party and the power it had to connect capitalists to the state bureaucracy is one example of the ways in which monopoly capitalism, privatisation, and the state were connected. In other words, the state did not take a back seat in deference to the market. This follows a pattern across Africa, where industrialisation and state-led capitalist development were seen as the means to end imperial domination.

In the conventional approach, the Sadat era is also identified as a major point of rupture. A historical materialist approach, however, would show that while there certainly was a point of rupture here - Infitah and the opening up of the Egyptian economy — many of the tendencies that emerged during this period were a result of the preceding shifts under Nasser. Here it becomes important to analyse continuities as well as ruptures. In other words, had the Nasser regime opted for a different course, it is possible that Egypt would have taken a different direction under Sadat. Finally, a focus on production would allow for the recognition of a final rupture — often overlooked in the literature- that occurred in the mid2000s. This refers to the emergence of a new influential group within the ruling class, headed by Gamal Mubarak. It is here that some of the tendencies introduced during Sadat materialised, including the increased pace of neoliberalisation. This rupture would only be discernable through a focus on production. Moreover, it is arguably this rupture that is the culmination of the various tendencies dating back to Muhammad Ali, as well as the final trigger for the 2011 revolution.

De Smet has traced similar continuities and disjunctures in his book, and in doing this has shown the importance of a complex historical analysis tied to production. The book is structured in a way that brings to light Egypt's modern political and economic trajectory, as a means through which we can understand the events of 2011. Indeed these events turn out to be yet another juncture along the trajectory of modern Egyptian history, bringing us ultimately to Abdelfattah al Sisi. De Smet points out that the 
Caesarism of Sisi —although evoking memories of Nasser — was essentially reactionary. It was neither antiimperialist nor nationalist in any material sense, and the promises of building a new society to displace an older one were shallow. The counter-revolutions of 2011 and 2013 bring to light a fact that has become increasingly important in any analysis of Egypt's political and economic history: throughout successive revolutions and counter-revolutions, it is Nasser's Caesarism that stands out as having been productive of a new society, built on the destruction of an old one. In other words, not all junctures are equally progressive. It is because of Egypt's position within global capitalism, and the resulting imbrication of most fractions of capital within these transnational relations, that only a hegemonic project based on antiimperialism and nationalism would target these very dynamics and therefore have a chance of changing them.

There is little doubt that the Nasserist historic bloc, led by the military, is particularly important in understanding modern Egypt, even more so following the creation of a new historical bloc in 2013 with the military at the centre. It is an extremely controversial one, and there have been endless debates about whether the Arab socialism propagated by the bloc was actually socialism; whether the bloc was good for labour or not; whether the social welfare reforms changed anything structural; and so on (see: Aoude 1994, Ayubi 1992, Hosseinzadeh 1998, Hussein 1973). In his book De Smet argues that the Free Officer coup of 1952 represents an example of Caesarism, and that without Nasser's intervention a true social revolution may have happened. I argue that this understanding of 1952 ignores the important fact that by dismantling the agrarian fraction of capital, the Nasserist bloc paved the way for the possibility of structural reform that in the long run would have been better for labour, as well as the fact that prior to 1952 it was the Wafd that was most likely to have won the battle between foreign capital and Egyptian workers. These two facts should be part of any analysis and may raise questions about viewing 1952 as an example of regressive Caesarism. Indeed it is within this context that we should understand popular support for the military post2013: it remains the only social force to date that had, at least at the start, a hegemonic project that benefitted wide segments of Egyptian society. This can be tied to various factors, including the class composition of the Free Officers themselves (especially compared to previous and successive ruling classes), as well as their focus on productive capital.

The second half of the book, which focuses on applying the Gramscian concepts expanded upon in the first section to the particular case of Egypt, begins with an analysis of the British colonial period. The 
deindustrialisation of Egypt by foreign capital and the influx of foreign commodities into Cairo were central aspects of the development of capitalism in Egypt. Uneven and combined development provides a lens through which these developments can be understood. This refers to the key Marxist concept that capitalist development has historically been uneven, leading to different capitalist formations across the globe. Scholars such as Ernest Mandel (1970) have taken this further to argue that imperialism made it impossible for non-industrialised countries to develop in the same way as imperialist countries. As in the first part of the book, De Smet historicises and contextualises the concept of uneven and combined development, in order to show how it is relevant to an analysis of the Egyptian case. Specifically, one of the effects of this type of development was a weak and ineffective national bourgeoisie:

Its accumulation strategy was primarily based on parasitic rentier activities rooted in landed property and commerce, which fettered industrialization. The idea that this national bourgeoisie would lead a class alliance to escape imperialism, develop the nation on a capitalist base, and 'catch up' with the advanced countries, was ridiculous, as this class was effectively the local form of appearance of imperialism. (91)

This dynamic is highlighted in the period starting with the 1919 revolution until the 1952 revolution, as De Smet shows the ways in which different fractions of capital in Egypt were tied to the dynamics instigated by foreign capital. Bank Misr, for example, was not strong enough to compete with foreign capital and represented the failure of Egyptian national capital to displace its foreign counterpart and the interests of international capital. This view critiques the argument made by some scholars that Egyptian national capitalists chose not to industrialise or develop independently of British control; ${ }^{2}$ instead De Smet clearly shows that British imperialist intervention consistently reinforced a power dynamic through supporting landed property owners, the monarchy and money capital in opposition to domestic industrial capital.

This argument is useful vis-à-vis the current situation in Egypt. In my own work I look at the ways in which the creation of the Egyptian bourgeoisie through colonialism and European penetration has meant that attempts to industrialise have been sidelined. This has created a native class that has been historically determined and is tied into global capitalism in ways that continue to make foreign capital and investment central to economic growth. We see today the Gulf capital and investment has become dominant, playing a central role in reproducing the Egyptian ruling class. It is no wonder then, that Gamal Abdel Nasser, the Free Officers and the Egyptian military as a whole were seen as a force that could act in Egypt's developmental interests in place of the national bourgeoisie that was dependent and weak. This, again, was

\footnotetext{
${ }^{2}$ See Vitalis (1995).
} 
not unique to Egypt but apparent across the African continent. In order to understand positive responses to the military take-over in 2011 and 2013, De Smet historicises these popular responses by tracing the lineage of Nasserism:

The imaginary of the Armed Forces as a potential revolutionary ally was not only the product of a simple naivety of the masses toward the real interests of the military, or, conversely, a calculated pragmatism not to confront the armed bodies of the state, but it also represented deeply entrenched historical expectations of the army as a national and popular force of change. This lineage was firmly rooted in the Nasserist experience of the 1950s and 1960s, which still resonated in contemporary Egyptian politics. Fragments of Nasserist ideology were still entrenched within popular common sense notions about social justice, relations between 'state' and 'economy', and anti-imperialism. (104)

In his discussion of nationalisation and land reforms, De Smet argues that Nasser carried these out in order to exclude landlords from the new historic bloc and that no nationalisation of land occurred $(2016,107)$. De Smet posits that the Free Officers' coup represented a Caesarist intervention because it, in effect, deflected the revolutionary process. Subaltern Egyptians were not seen as revolutionary subjects, making the 1952 revolution a reactionary rather than revolutionary project. This project was undone under Sadat, during which there was a strengthening of private capital alongside a weakening in the power exercised by labour. This marked the start of the neoliberal era in Egypt.

I would question this writing off of Nasser's land reforms and instead pose the question of whether the limited achievements of the Nasserist bloc should not be contextualised within a broader set of questions of imperialism, decolonisation, and capitalism, rather than solely attributed to the failures of the bloc itself. Here the context of decolonisation is key: there were social forces working against independence, most notably the agrarian fraction of capital, and land reforms - among other interventions - successfully dismantled the power of these forces. The Nasserist bloc should be placed within its global moment just as the Sadatist bloc should be placed within the global emergence of neoliberalism. Without the dismantling of the agrarian fraction, it is likely that Egypt would have continued along the same trajectory put in place by British colonial rule. De Smet's argument mirrors one made by Egyptian Marxists of the 1960s, namely that the Free Officers had deflected the real revolutionary process (Abdel-Malek 1968; Hussein 1973). This view should be problematised in light of what the Nasserite bloc did achieve - a dismantling of a fraction of capital closely tied to foreign capital, the introduction of social reforms, and an attempt to industrialise the productive base of the Egyptian society.

It is also useful to contextualise this within broader shifts on the African continent. Much ink has been spilled criticising the failures of post-independence leaders and parties. It may be more productive, 


\section{S. Salem}

especially given our current moment, to instead ask what these historical blocs did achieve; in what ways did they break away from imperial patterns? Nasser and other African leaders such as Nkrumah, Kaunda, Lumumba and Nyerere saw the importance of rearticulating the position of these countries to the international, a space constituted through inequality. That was the priority, as that was the only means through which independent development could take place. It was this moment that saw an attempt to break away from Fanon's model of a "dependent bourgeoisie" (1963) and instead engage in industry and invention in order to strengthen the productive base of the economy. This also provides much-needed context in understanding why the military enjoy a high level of popularity in Egypt today; it remains the only institution that has, historically, provided the material conditions that benefitted large segments of Egyptian society. For these reasons, I argue it is more useful to see this particular moment as nuanced rather than as a clear failure on the part of the historical bloc in place.

In sum, De Smet provides a strong argument for why Gramsci's work on passive revolution continues to be relevant today. This work-inspired by the question of why and how capitalism continues to survive - as well as the important intervention on Egypt and the 2011 revolution by De Smet—serve to direct us to the very question of capitalism's survival today, and its connection to revolutionary movements around the world.

Connected to this focus on capitalism is Gilbert Achcar's book, The People Want (2013). Achcar has a much more sombre reading of the events in Egypt, which he argues are not a revolution but rather a series of uprisings (Achcar 2013, 6). Despite this, he does conceptualise these events as part of a long-term revolutionary process. Achcar brings our attention to the shift from public to foreign investment as part of the process of neoliberal transformation in the Middle East, writing: '[o]n the one hand, these facts suggest that most of the blame for the lamentable state of the region must be put on the drop in public investment induced by the change in economic paradigm at the regional and global levels. On the other hand, the same facts lead us to ask why private investment has not climbed from levels too low to offset the withdrawal of public sector investment' $(2013,63)$. Achcar points out that the results of Nasser's 1961-1965 five year plan were better than the results of the Mubarak era-despite Egypt's involvement in the war in Yemen under Nasser-raising questions about the discourse about public sector inefficiency and privatisation as a solution to economic problems. As Achcar notes, the change in economic paradigm at the global and regional levels explains this shift. I would question, however, his downplaying of the levels of private 
investment. Post-2004 they have reached high levels—particularly because of Gulf capital—which means that they may have offset the withdrawal of public sector investment empirically, but also that they have created a new range of social, economic and political problems that public funding had attempted to alleviate throughout the Nasser era.

In his discussion of workers, Achcar argues that workers have been repressed for decades through both despotic states and through official trade unions that have been co-opted. Although he does mention privatisation, he does not discuss the ways in which it affected workers as part of the broader process of neoliberalisation that was underway. He notes, for example, that in 2004 we saw a rapid increase in the number of workers' strikes, without making reference to what happened within Egypt's ruling class in that year: the emergence of a new faction centred around Gamal Mubarak that accelerated many of the neoliberal policies put in place by Sadat $(2013,156)$. This formalised itself in 2004 with the emergence of a cabinet dominated by businessmen. Nevertheless, Achcar's book does a great service to the literature because of his focus on the global, the regional and the local, as well as his consistent attempts to bring imperialism and hegemony into the analysis. Moreover, his analysis of the Muslim Brotherhood as part of the Egyptian bourgeoisie is important in light of the tendency to represent them ahistorically, or as a revolutionary force $(2013,278 f$.).

For a more detailed discussion of the role of neoliberalism in Egypt's revolution, I turn to Maha Abdelrahman's A Long Revolution (2014). Abdelrahman starts her book with an accurate description of the problems with much of the scholarship on Egypt:

Arab countries and their people have always posed a challenge to commentators and analysts of the region as they have systematically failed to act in ways expected of them. Arab countries were at the 'bottom of the class' after the third wave of democratization had come and gone. The inability of the region to join other countries in ridding themselves of dictatorial regimes gave rise to a robust industry devoted to deciphering the enigma of this anomaly, looking for signs everywhere but mostly in the dark recesses of the regime's cultural and religious systems or, occasionally, in a reductionist version of the 'rentier' thesis. $(2014,1)$

Abdelrahman is one of the few scholars on Egypt to put forward the compelling argument that crony capitalism works hand-in-hand with neoliberalism; it is not an aberration but very much an effect of the neoliberalisation of Egypt. The replacement of the powerful public sector with private monopolies has been the outcome of the privatisation process, and the defining feature of the new ruling class. However this was accompanied by increasing levels of corruption. Many businessmen during the 1990s and 2000s achieved a level of independence and power unseen for decades. As Abdelrahman notes, the state and the call for low taxes of businesses was part of this overall picture. By 2001, taxes on industrial and commercial profits 
amounted to a mere 4.4 per cent $(2014,15)$. This worsened under the 'cabinet of businessmen', during which the corporate tax was cut from 42 to 20 per cent. By 2009, salaried workers paid a total of LE13 billion in taxes while corporations paid only LE29 billion $(2014,15)$.

Importantly, Abdelrahman has intervened in the debate on Egyptian workers by pointing to the ways in which workers' demands were very much political. This is in response to claims that workers in Egypt made purely economic demands and were thus not central to the (political) revolutionary project. In a previous piece, Abdelrahman has argued:

Examining the nature of the demands of workers and unorganized groups of citizens, one can easily see their overtly political character. By demanding potable water and effective garbage collection, disempowered and marginalized groups have been bringing the state and its agents to account and putting pressure on its institutions to be responsive and accountable in the only way that was left open to them. Similarly, labour protest to demand better pay and secure jobs is necessarily a political act. While the failure to see labour strikes and market-relations-based protests for economic benefit as truly political is a huge analytical oversight, the unwillingness to see the growing 'political' demands of Egyptian labour during the last decade is tantamount to blindness. $(2012,620)$

Categorising workers as non-threatening because their demands are economic — and not political—not only reproduces the problematic binary between the two but also serves to hide the fact that economic demands are by nature political. In other words, any demand to change the structure of production affects accumulation, which in turn touches the very heart of politics: the ruling class. Abdelrahman goes on to give the great example of workers' demands for economic security being highly political because they reference the Nasserist ruling class, thus making a clear statement about the decay of the political order. In A Long Revolution, Abdelrahman makes a similar point, writing that 'a compartmentalization of different forms of resistance based on the content of their demands, assumes an impossibly neat separation between economic and political struggles' $(2014,118)$. Because of the capitalist system, which localises conflict, labour protests are seen as separate from politics $(2014,118)$.

Abdelrahman further highlights that the 2006 Mahalla strike prompted a different response to previous labour strikes from Egypt's ruling class. Whereas before, particularly during Sadat, we see that the ruling class often gave in to worker demands and that a process of negotiation took place, the violent repression at Mahalla suggests a shift in tactic. As Abdelrahman notes, the new dependency on negotiation and settling labour disputes rather than using raw violence demonstrated what she calls 'the new variant of capitalism in Egypt', represented by a new type of business owner that uses cost-benefit analysis rather than direct violence $(2014,15)$. While this may seem positive on the surface, it is useful to remember that 
this shift also came with increasing insecurity in the workplace in terms of job contracts, salaries, pensions, and social services.

Abdelrahman's book is one of the more critical interventions in the literature on the 2011 Egyptian revolution. She clearly locates the events of 2011 within a longer historical trajectory, and centres both neoliberalism and workers' struggles in an attempt to show how capitalism continues to have clear effects on countries in the Middle East. Read alongside Achcar and de Smet, the story of the revolution is presented as complex, contradictory, but also hopeful. It is a story of both domination and resistance; stagnation and change. Above all, it is a story that is often left out: a story about global, regional, and local power. 


\section{S. Salem}

\section{Note on contributor}

Sara Salem is a Research and Teaching Fellow in the Department of Politics and International Studies at the University of Warwick.

\section{Disclosure statement}

No potential conflict of interest was reported by the author. 


\section{Bibliography}

Abdel-Malek, Anouar. 1968. Egypt: Military Society. New York: Random House.

Abdelrahman, Maha. 2012. "A Hierarchy of Struggles? The 'Economic' and the 'Political' in Egypt's Revolution." Review of African Political Economy 39 (134): 614-628.

Abdelrahman, Maha. 2014. Egypt's Long Revolution: Protest Movements and the Uprisings. Abingdon: Routledge.

Achcar, Gilbert. 2013. The People Want: A Radical Exploration of the Arab Uprisings. London: Saqi.

Aoudé, I. (1994) "From national bourgeois development to "Infitah": Egypt 1952-1992." Arab Studies Quarterly vol. 16, no. 1, pp. 1-23.

Ayubi, N. (1992) "Withered socialism or whether socialism? The radical Arab states as populist-corporatist regimes," Third World Quarterly vol. 13, no. 1, pp. 89-105.

Bellin, E. (2012) "Reconsidering the robustness of authoritarianism in the Middle East: lessons from the Arab Spring." Comparative Politics vol. 44, no. 2, pp. 127-149.

De Smet, Brecht. 2016. Gramsci on Tahrir: Revolution and Counter-Revolution in Egypt. London: Pluto.

Fanon, Frantz. 1963. The wretched of the earth: The handbook for the black revolution that is changing the shape of the world. New York: Grove Press.

Hosseinzadeh, Esmail. (1988) "How Egyptian State Capitalism Reverted to Market Capitalism," Arab Studies Quarterly, vol. 10, no. 3, pp. 299-318.

Hussein, Mahmoud. 1973. Class Conflict in Egypt, 1945-1970. New York: Monthly Review Press.

Mandel, Ernest. 1970. “The laws of uneven development.” New Left Review vol 59, no. 19.

Osman, T. (2010) Egypt on the brink: From Nasser to Mubarak. Providence: Yale University Press.

Stacher, J. (2012) Adaptable autocrats: Regime power in Egypt and Syria. Stanford: Stanford University Press.

Vitalis, Robert. 1995. When Capitalists Collide: Business Conflict and the End of Empire in Egypt. Berkeley, CA: University of California Press. 